\title{
Oxalic acid for the control of varroosis in honey bee colonies - a review ${ }^{1}$
}

\author{
Eva RADEMACHER*, Marika HARZ \\ Free University of Berlin, Dept. of Biology/Chemistry/Pharmacy, Neurobiology, Königin-Luise-Str. 28-30, \\ 14195 Berlin, Germany
}

Received 17 February 2005 - revised 17 June 2005 - accepted 26 July 2005

\begin{abstract}
The review summarizes research results on the use of oxalic acid as an acaricide in honey bee colonies. Three different treatment techniques (i.e. trickling, evaporation and spraying) have been developed for the application of oxalic acid. Detailed information is given on the efficacy against Varroa destructor, tolerability by Apis mellifera, protective procedures for the user, residue situation and consumer safety, as well as recommendations for use.
\end{abstract}

oxalic acid dihydrate / varroosis / honey bee / residues

\section{INTRODUCTION}

In the middle of the 20th century Varroa destructor moved onto the Western honey bee, Apis mellifera, as a new host and subsequently spread globally. Because there is no natural balance between the new host and parasite; $V$. destructor destroys honey bee colonies within a few years. Since $V$. destructor appeared in $A$. mellifera colonies beekeepers have been forced to use acaricides regularly to keep mite populations under control. In Europe, many beekeepers rely on coumaphos and synthetic pyrethroids to control varroosis. Over the last 10 years the mite's resistance to synthetic acaricides has increased tremendously, necessitating a new strategy to combat $i$, including the development of new veterinary medications (Elzen et al., 1998; Lodesani et al., 1995; Milani, 1995; Moosbeckhofer and Trouiller, 1996; European Group for Integrated Varroa Control, 1999).

Due to the biology of host and parasite, different treatment methods are required during the year (Concept of Integrated Varroa Control). Biotechnical methods such as the removal of drone brood and the use of trapping combs (Arbeitsgemeinschaft der Institute für Bienenforschung, 2001) and formic acid or thymol (Imdorf et al., 1999; Rademacher, 1995, 1996; Rademacher et al., 1999) can be used to reduce mite populations during the summer months. During autumn and winter months the bee colonies can be treated with lactic acid or oxalic acid (Charrière and Imdorf, 2002; Kraus et al., 1993; Nanetti et al., 2003a). Lactic acid is only practical for small apiaries. Within the Concept of Integrated Varroa Control, autumn treatment of large apiaries is based on the use of oxalic acid. This substance provides a wide range of possible application methods at the appropriate time for the year.

Oxalic acid has been known to be effective against $V$. destructor since the end of the 20th century (Popov et al., 1989). Most investigations into the development of oxalic acid as a drug in bee colonies have been carried out in EU countries and Switzerland using three

\footnotetext{
* Corresponding author: radem@zedat.fu-berlin.de

${ }^{1}$ Manuscript editor: Stefan Fuchs
} 
different application forms. The European Group for Integrated Varroa Control tested oxalic acid in coordinated experiments. Their aim was to provide beekeepers with a fully developed treatment method (Nanetti et al., 2003a). To use oxalic acid legally it must be registered as a drug for bees; to achieve approval, each country's legislation must be considered (Mutinelli and Rademacher, 2002). This review presents and evaluates current knowledge about oxalic acid with regard to its applicability as a control for $V$. destructor. In addition to the scientific literature, we have included articles from practical beekeeping journals, because many studies were only published there.

\section{EFFICACY OF OXALIC ACID AGAINST VARROA DESTRUCTOR AND TOLERABILITY BY APIS MELLIFERA}

\subsection{Trickling}

Using a syringe or a similar applicator, oxalic acid dihydrate solution was trickled directly onto the bees in the spaces between combs, normally when colonies were in the broodless phase. The application is quick (about 1 min per hive), cost-effective and easy. Trials were conducted in Southern, Central and Northern Europe as well as North America when outside temperature ranged from 3 to $13{ }^{\circ} \mathrm{C}^{1}$. The investigations are listed in Table I, grouped by climatic area, season, number of applications and concentration of oxalic acid dihydrate solution.

\subsubsection{Efficacy}

The majority of trials were conducted in moderate climates in Central Europe. The investigators focused on the application of oxalic acid in autumn when colonies are broodless, as oxalic acid does not kill the mites in sealed brood cells.

Single treatments during autumn were evaluated by applying $5 \mathrm{~mL}$ per bee space (30$50 \mathrm{~mL}$ per hive) of various concentrations of

\footnotetext{
${ }^{1}$ Temperature not mentioned in all papers.
}

oxalic acid dihydrate. A concentration of $3 \%$ oxalic acid dihydrate provided an efficacy of $>90 \%$ in most trials (Charrière, 2001; Charrière and Imdorf, 2002; Nanetti et al., 2003a); only in one investigation was an efficacy $<90 \%$ described (Nanetti et al., 2003a). A 3.5\% solution provided $>95 \%$ (Charrière and Imdorf, 2002; Charrière et al., 2004). A lower dose of $10-15 \mathrm{~mL} /$ hive $(3.5 \%)$ showed a similarly good acaricidal effect (98\%) when smaller colonies were treated (2-Zanderflachzargen, Moosbeckhofer, 2001).

Büchler (2000) quantified a dose per bee after estimating colony size. The applied dosage was $3 \mu \mathrm{L}$ per bee. A dose of $22 \mathrm{~mL}$ (small colonies, approx. 7400 bees) and $79 \mathrm{~mL}$ per hive (very strong colonies, approx. 26500 bees) respectively, reached an efficiency of $91.3 \%$ using $3 \%$ oxalic acid dihydrate solution. When a $4.6 \%$ oxalic acid dihydrate solution was applied, mite mortality increased to $98.4 \%$. The overall dosage in the trials $(22 \mathrm{~mL}$ with $4.6 \%$ and $79 \mathrm{~mL}$ with $3 \%$ ) equalled $5 \mathrm{~mL}$ per bee space at $3.5 \%$ oxalic acid dihydrate solution. Trials using lower dosages $(3.2 \mathrm{~mL}$ per bee space) and $3 \%$ oxalic acid dihydrate showed a reduced efficacy of only $84.8 \%$ (Büchler, 1999). Higher oxalic acid dihydrate concentrations of 4.6 and $6 \%$ (3.2 mL per bee way) killed $92.2 \%$ and $94.3 \%$, respectively, of the mites parasitizing the colonies (Büchler, 1999).

Applying a similar overall dose, but dividing the dose per bee in half in one group (3.0 and $1.5 \mu \mathrm{L}$, respectively) and doubling the concentration from 2.3 to $4.6 \%$ oxalic acid dihydrate resulted in an obviously higher efficacy of $98 \%$ ( $2.3 \%$ solution) and $80 \%$ mite fall using the high oxalic acid dihydrate solution (4.6\%; Büchler, 2000).

Trials in which more than $3.5 \%$ oxalic acid dihydrate solution were applied showed that higher dosages do not clearly lead to an increased efficacy (Charrière, 2001; Charrière and Imdorf, 2002; Liebig, 1998; Nanetti et al., 2003a). There is a tendency that the highest concentrations and doses of 6 or $8 \%$ (Liebig, 1997, 1998) actually reduced the efficacy. Using these high dosages to combat varroosis is not feasible because the bees cannot tolerate them (see Sect. 1.1.2 Tolerability).

During summer in breeding colonies the efficacy was reduced to $36 \%$ (Schuster and 


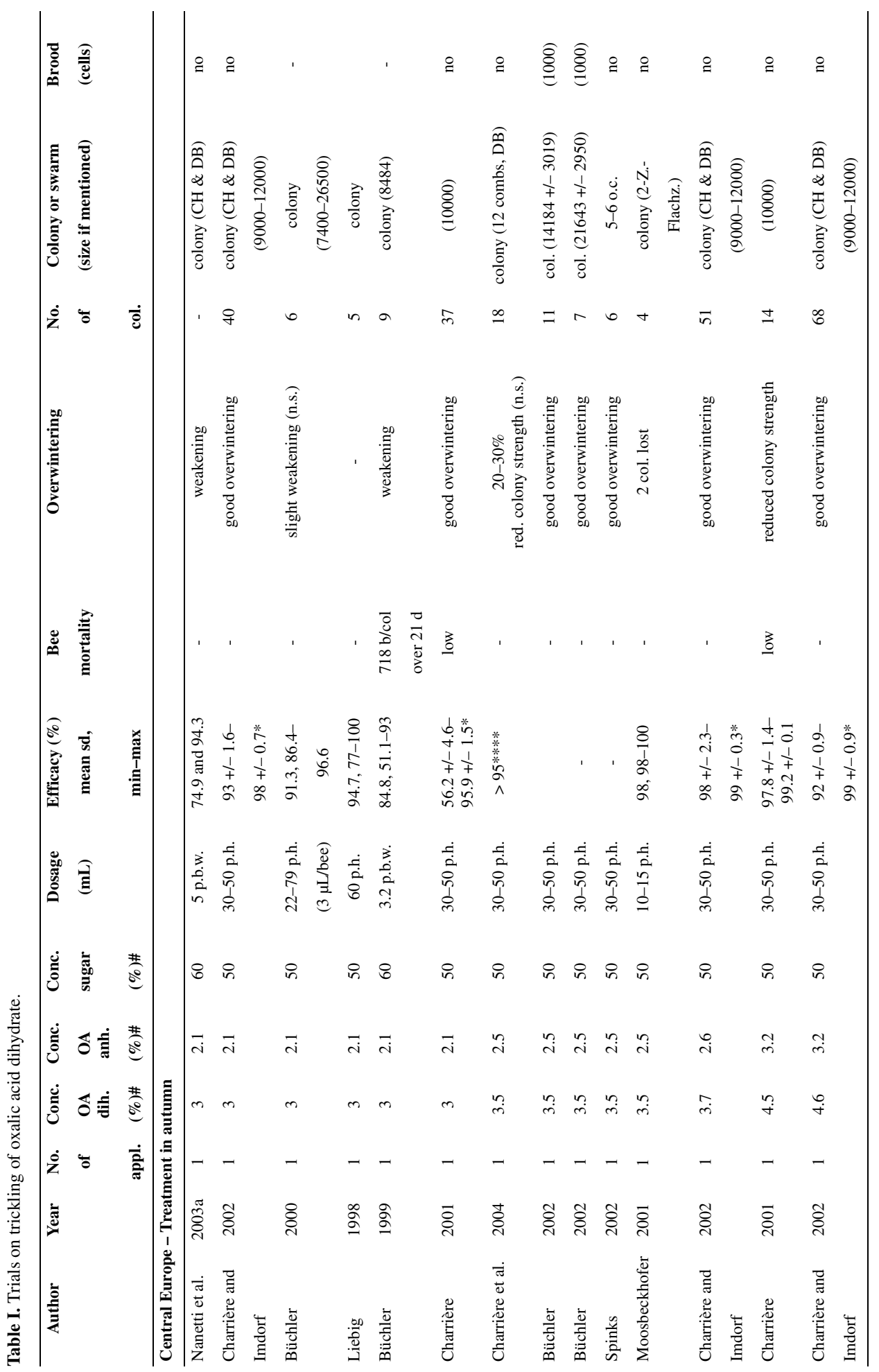




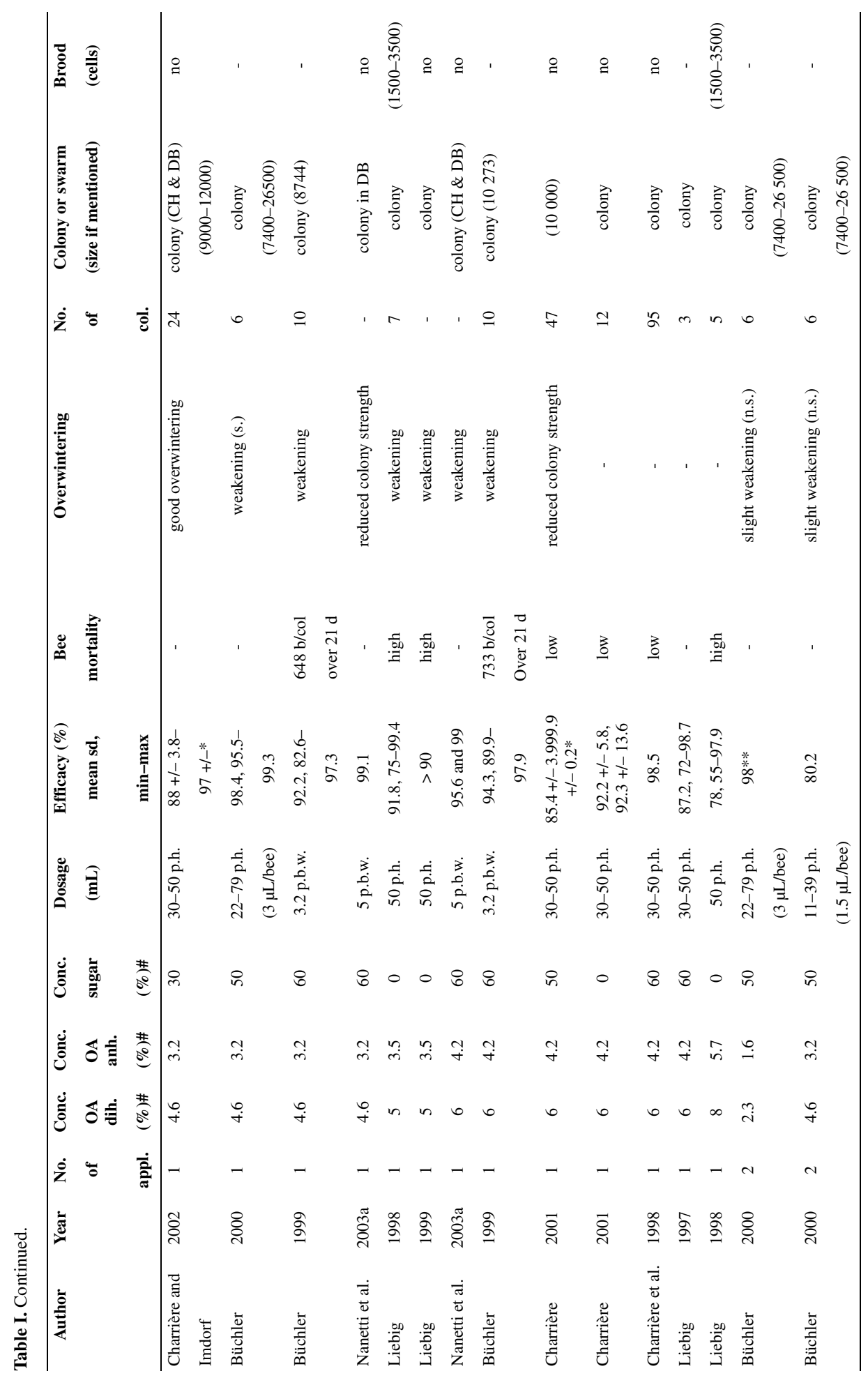




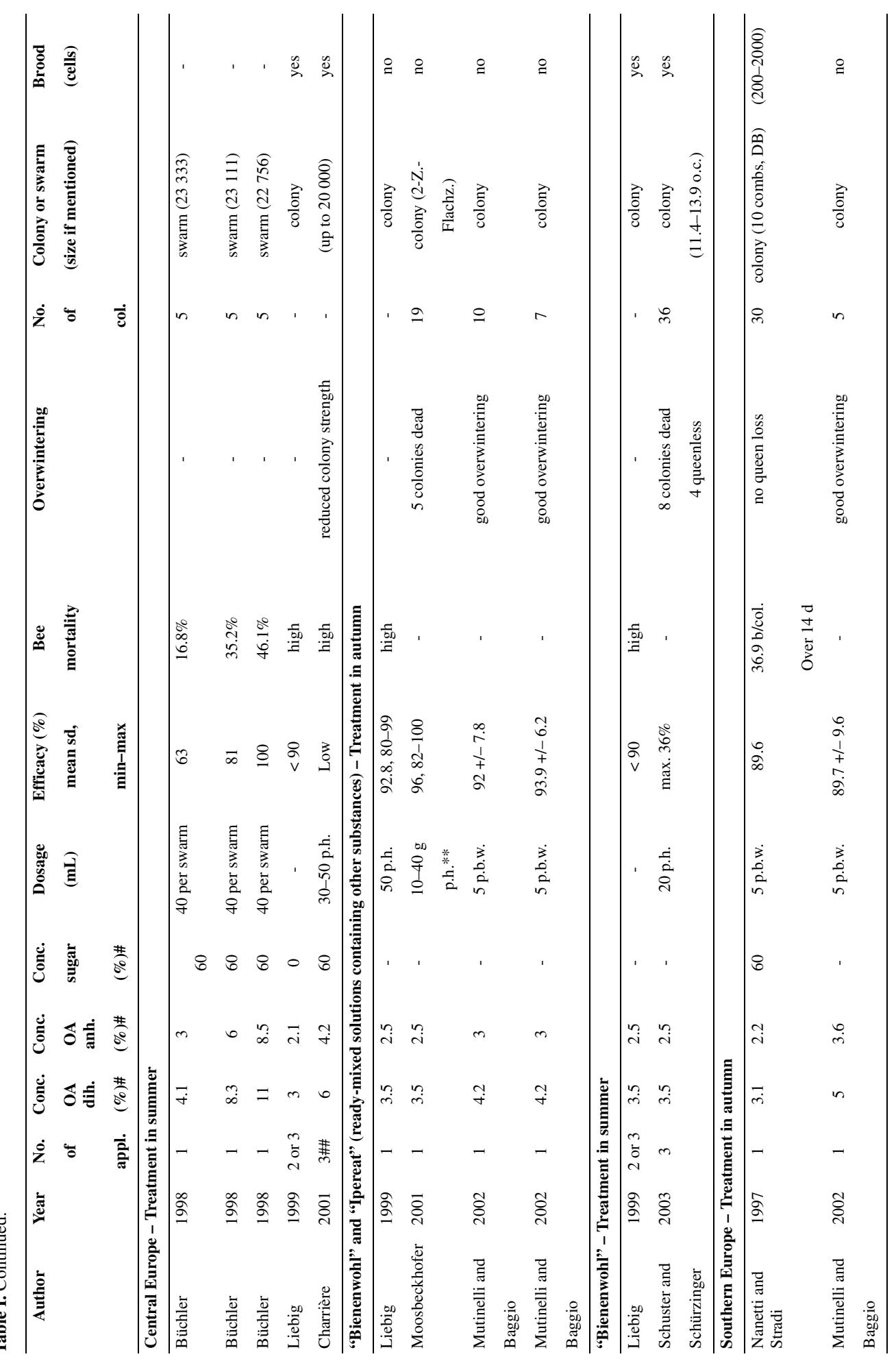




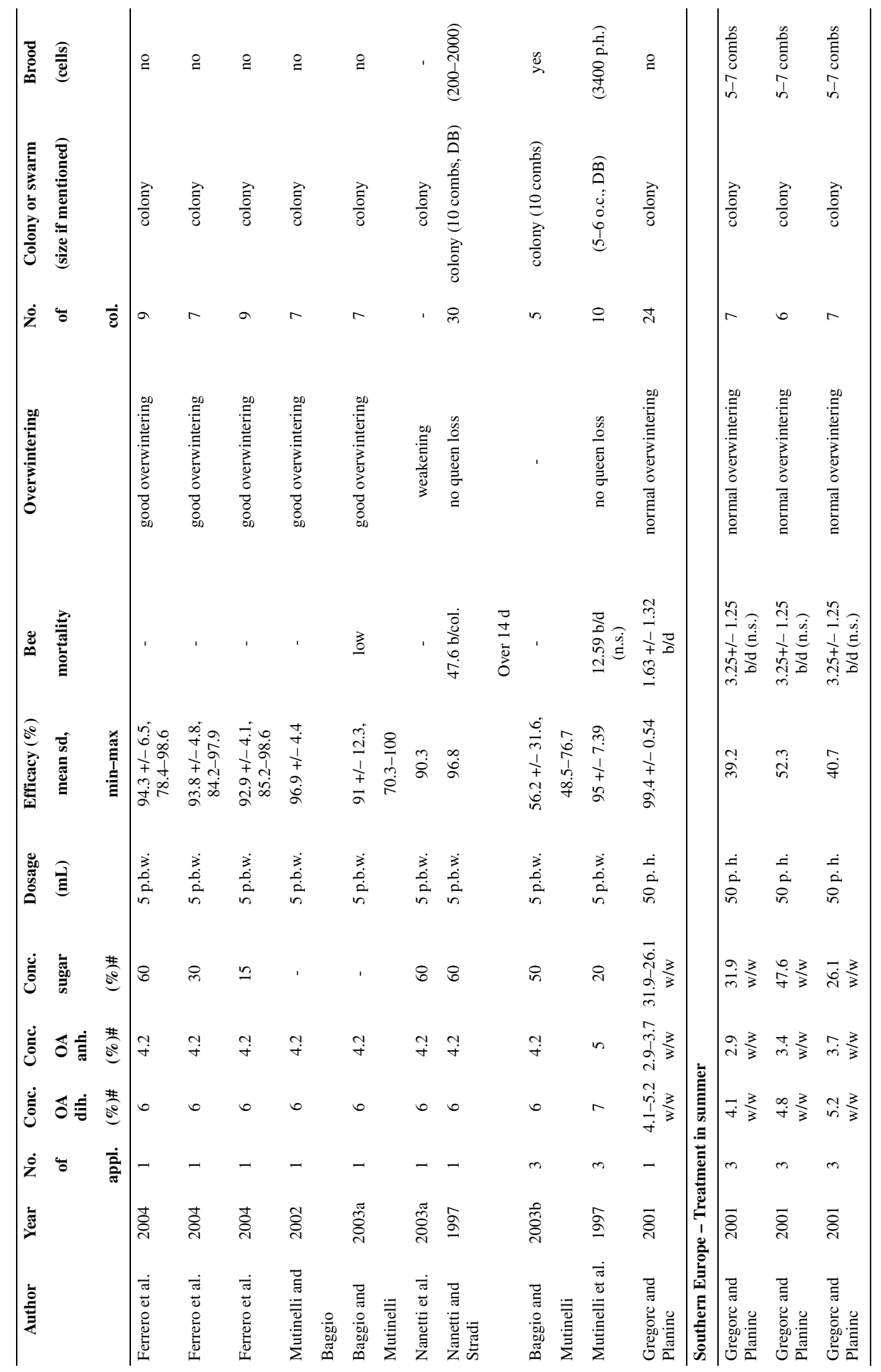




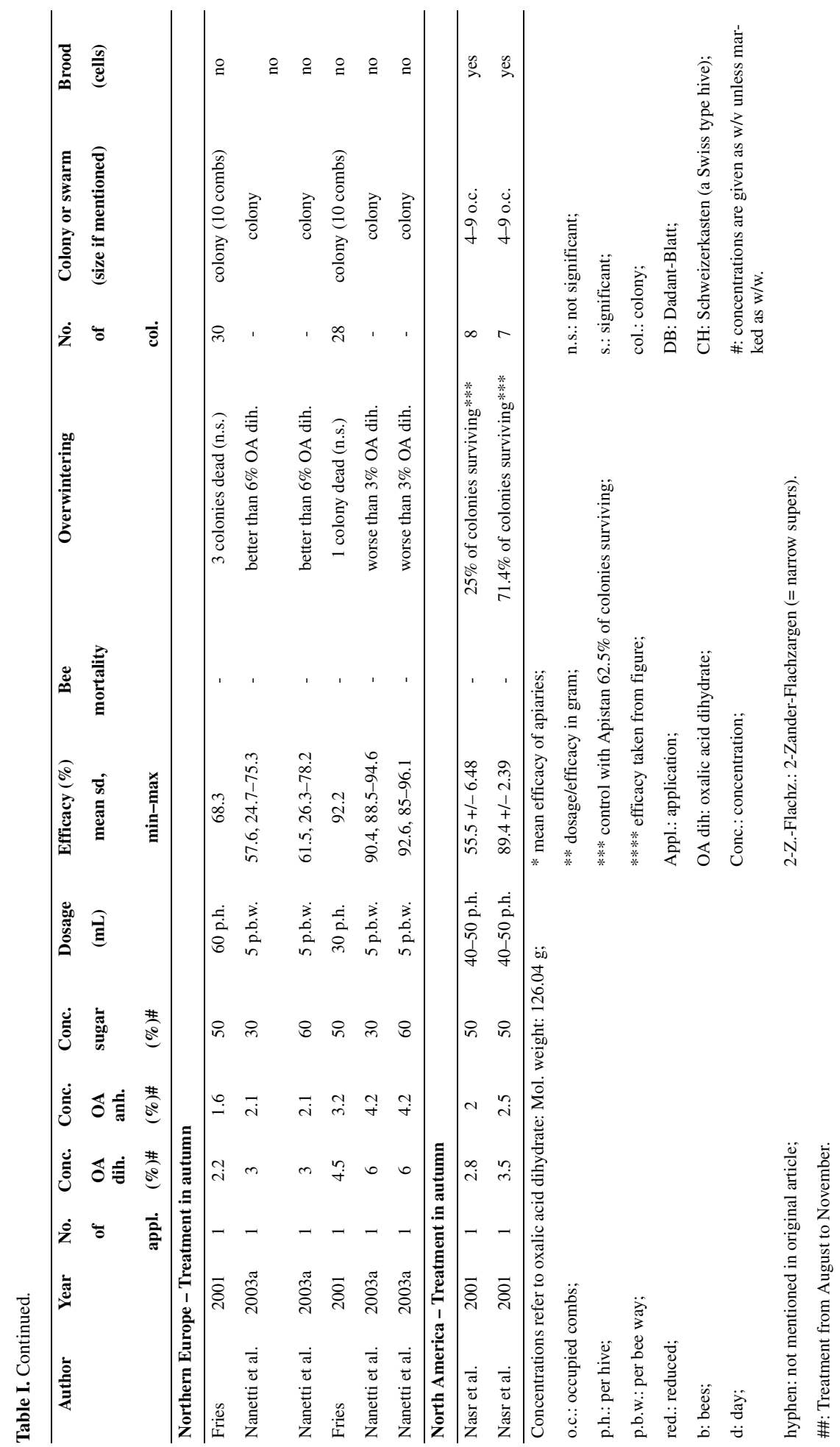


Schürzinger, 2003). The presence of brood seemed to be the main reason for low mite mortality in summer treatments. An efficiency of up to $100 \%$ was reached in broodless artificial swarms (Büchler, 1998).

Investigations from Canada in a climatic region comparable to Central Europe confirmed the results of autumn treatments: $2.8 \%$ oxalic acid dihydrate solution ( $40-50 \mathrm{~mL} /$ hive $)$ killed about $55 \%$ of the mites, $3.5 \%$ about $90 \%$ in colonies with remaining brood (Nasr et al., 2001).

Different concentrations of oxalic acid were found to be effective depending upon the European climatic region. A higher oxalic acid dihydrate concentration appeared more suitable in a southern climate. Treatments with $6 \%$ oxalic acid dihydrate, $5 \mathrm{~mL}$ per bee way, resulted in an efficiency of $>90 \%$ and $>95 \%$, respectively, while treatments with 3.1 and $5 \%$ oxalic acid dihydrate resulted in $<90 \%$ (Ferrero et al., 2004; Mutinelli et al., 1997; Mutinelli and Baggio, 2002; Nanetti and Stradi, 1997; Nanetti et al., 2003a).

Only one investigation resulted in high mite mortality of $99 \%$; low concentrations of 4.1$5.2 \%$ oxalic acid dihydrate were applied in varying sugar solutions calculated as w/w (Gregorc and Planinc, 2001). For comparability, this corresponds to approximately 4.5$5.9 \%$ oxalic acid dihydrate w/v as described in other studies.

Repeated treatments with a high concentration $(6$ and $7 \%)$ did not increase the efficacy (Mutinelli et al., 1997); one study even described a reduced mite mortality of $56.2 \%$ (Baggio and Mutinelli, 2003b).

Mutinelli and Baggio (2002) applied Ipereat, a ready mixed solution containing about $4.2 \%$ oxalic acid dihydrate, ethereal oils, propolis and sugar and reported efficacies up to $93.9 \%$.

Gregorc and Planinc (2001) treated colonies with brood three times in the summer by applying 4.1-5.2\% oxalic acid dihydrate in varying sugar solutions w/w corresponding to approximately $4.5-5.9 \%$ oxalic acid dihydrate w/v. An efficacy of 39-52\% was achieved.

In a northern climate, a concentration of 4.5 and $6 \%$ oxalic acid dihydrate was described as effective with $>90 \%$ mite fall, while lower concentrations (2.2 and $3 \%$ ) led only to approxi- mately 60\% efficacy (Fries, 2001; Nanetti et al., 2003a).

Most authors applied oxalic acid dihydrate in sugar syrup. By adding sugar to oxalic acid dihydrate solutions in a concentration of 50$60 \%$ the efficacy could be increased compared to 0 or $30 \%$ sugar (Charrière, 2001; Charrière and Imdorf, 2002; Nanetti et al., 2003a). The addition of higher concentrations of sugar increased the efficacy by about 5\% (Charrière, 2001).

\subsubsection{Tolerability}

In Central Europe, a single treatment with oxalic acid dihydrate solutions in autumn in most cases is well-tolerated by the bees in concentrations up to 4.6\% (Büchler, 1999, 2000, 2002; Charrière, 2001; Charrière and Imdorf, 2002; Charrière et al., 2004; Nanetti et al., 2003a; Spinks, 2002). A normal weakening of the colonies during winter was described, similar to controls (Büchler, 1999, 2000; Charrière et al., 2004; Nanetti et al., 2003a). Büchler and Charrière et al. observed in their repeated studies a slight, but not significant, tendency towards better overwintering of the controls (ANOVA; Duncan-test, $P>0.05$ ); the development of the colonies in spring of both groups was equal (ANOVA, Charrière et al., 2004). Relatively high bee mortality ( $8 \%$ ) was observed during 3 weeks after treatment with 3, 4.6, 6\% oxalic acid dihydrate and in the control group (Büchler, 1999). The author suggested that bad weather conditions during the time bees were flying could have caused the high mortality. Büchler (2002) found equivalent bee tolerability when comparing the treatments of $3.5 \%$ oxalic acid dihydrate, lactic acid and Perizin.

At a concentration of $4.6 \%$ oxalic acid dihydrate $(3 \mu \mathrm{L}$ per bee), the treated colonies showed a significant weakening during winter compared to controls (Duncan-test, $P<0.05$; Büchler, 2000). Studies with a higher concentration of $5 \%$ described doubled bee mortality in autumn, bad overwintering (reduced colony strength) of treated colonies and impaired spring development (Charrière, 2001; Liebig, 1998, 1999).

Multiple autumn or summer treatments (23) by trickling were poorly tolerated by the bees in this Central European region (Büchler, 1998; Charrière, 2001; Liebig, 1999). 
The ready-mixed solution "Bienenwohl" (oxalic acid, citric acid, alcohol, ethereal oils and propolis) applied repeatedly in late summer and autumn ( $20 \mathrm{~mL}$ per hive) can cause colony losses during the winter (Schuster and Schürzinger, 2003). A single application of $50 \mathrm{~mL}$ per hive in autumn induced high bee mortality over the winter period (Liebig, 1999). The losses of colonies in studies by Moosbeckhofer (2001) cannot be definitely attributed to the application of "Bienenwohl" or oxalic acid dihydrate, as the colonies were already weak at the beginning of the treatment. Mutinelli and Baggio (2002) reported good bee tolerability applying Ipereat (composed similarly to Bienenwohl).

Investigations in comparable climatic regions in Canada described bad overwintering with colony break down in both the oxalic acid and the Apistan groups. The damages could not be attributed to the oxalic acid treatment (Nasr et al., 2001).

It is noticeable that there are differences in tolerability in varying climatic areas. In Southern Europe, oxalic acid dihydrate concentrations up to $7 \%$ are tolerated (Gregorc and Planinc, 2001; Mutinelli et al., 1997; Mutinelli and Baggio, 2002; Nanetti and Stradi, 1997; Nanetti et al., 2003a) even if the bee colonies are treated 3 times. No losses of queens were reported and bee mortality did not increase. After winter, all colonies showed reduced size but the treated colonies did not differ from controls. In Northern Europe, bee tolerance of up to $6 \%$ oxalic acid dihydrate is described, but colony size after overwintering following treatment with $6 \%$ was slightly poorer than in colonies treated with $3 \%$ oxalic acid dihydrate (Nanetti et al., 2003a).

\subsection{Evaporation}

Oxalic acid dihydrate in the form of crystals, gelatine capsules or tablets was heat-evaporated (the correct chemical term is "sublimated") with different types of evaporators, predominantly during the broodless period. The application took about 4 minutes per hive and required complex equipment. The trials were mainly conducted in Central Europe, except for two studies from Southern Europe and Asia. Oxalic acid was applied at an outside temperature ranging from 2 to $16{ }^{\circ} \mathrm{C}^{2}$. The investigations are listed in Table II, grouped by type of evaporator, geography and oxalic acid formulation.

\subsubsection{Efficacy}

A Varrox evaporator was used in most trials. This is a small electrical heating device which can be inserted into the hive in the entrance and allows the evaporation of oxalic acid in the closed hive (Radetzki, 2000). This application device, with a dose of 1-2 g oxalic acid dihydrate (crystals, capsules or tablets), provided high acaricidal effectiveness of $>90 \%$, even $95 \%$ or more in most studies (Charrière et al., 2004; Imdorf et al., 2002; Radetzki et al., 2000; Radetzki and Bärmann, 2001). One exception was a study by Moosbeckhofer and Baumgartner (2002) with low efficacy (78\%), but the authors suggested that a very high mite population might have been the cause. In another study, carried out in Southern Europe, less than $90 \%$ mite mortality was reached (Baggio and Mutinelli, 2003a), but it is known from Nanetti and Stradi (1997, using the trickling method) that in southern climates higher oxalic acid dihydrate concentrations are needed to achieve high mite mortality. Ferrero et al. (2004) showed differences in efficacies over three years $(64 \%$, $93.9 \%, 97 \%$ ) after double administration of $2 \mathrm{~g}$ oxalic acid dihydrate. The author suggested that high humidity during treatment could have caused the low efficacy in one of the years.

A higher dosage of $2.8 \mathrm{~g}$ did not lead to an increased efficacy (Ferrero et al., 2004; Radetzki et al., 2000). Application of $3 \mathrm{~g}$ or $5 \mathrm{~g}$ (more than doubled dosage when compared to 1-2 g) oxalic acid dihydrate resulted in an efficiency of $99 \%$. Using a dose of $0.5 \mathrm{~g}$ oxalic acid dihydrate crystals per hive did not ensure sufficient effectiveness: Radetzki et al. (2000) achieved $82.8 \%$. The threshold for high efficiency seems to be $1 \mathrm{~g}$ per colony. This dosage should be used in single-story hives; larger hives should be treated with $2 \mathrm{~g}$ oxalic acid dihydrate (Radetzki (2004) - personal communication).

In colonies with brood a comparatively lower mite fall of $91.4 \%$ was achieved by

\footnotetext{
2 Temperature not mentioned in all papers.
} 


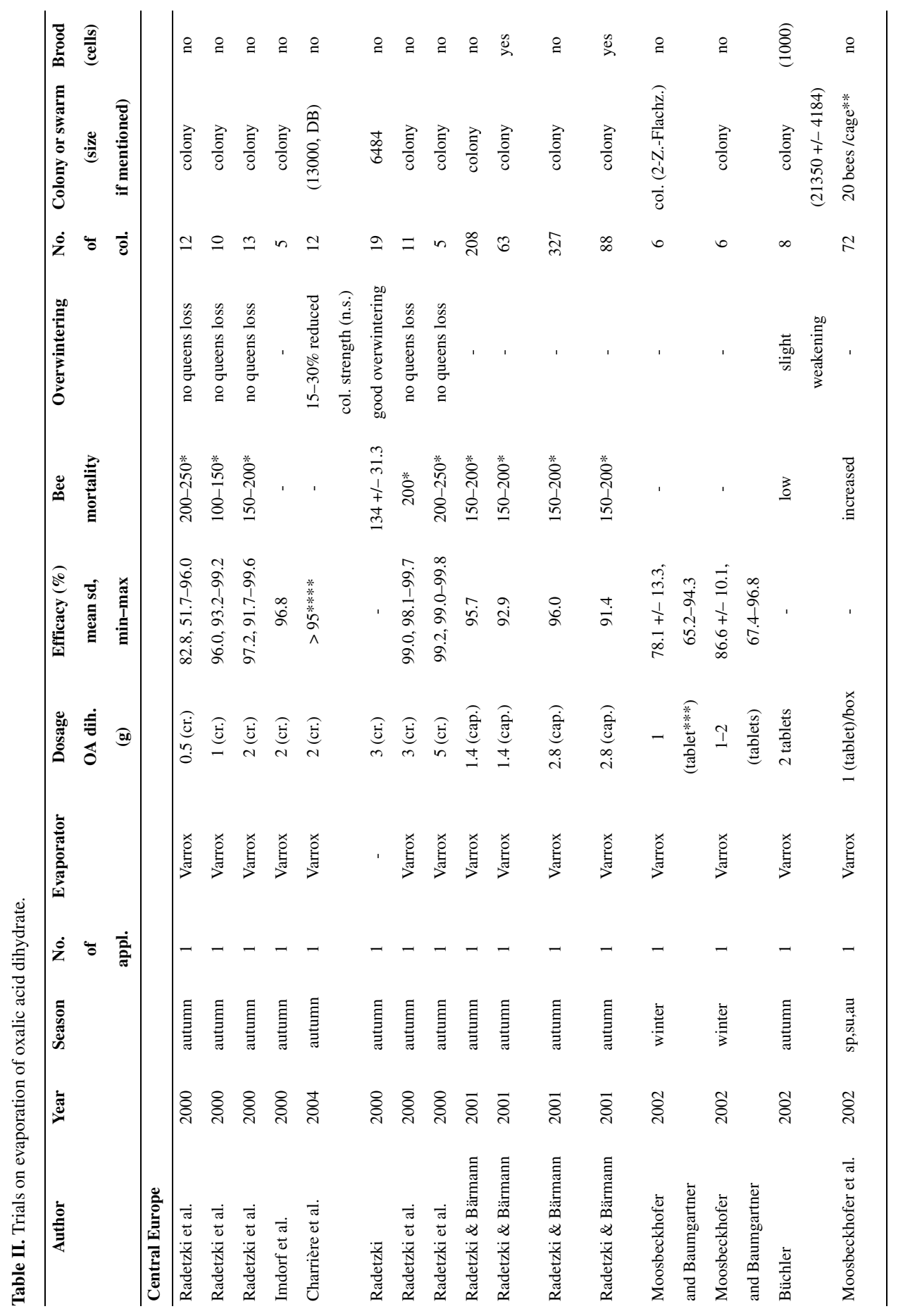




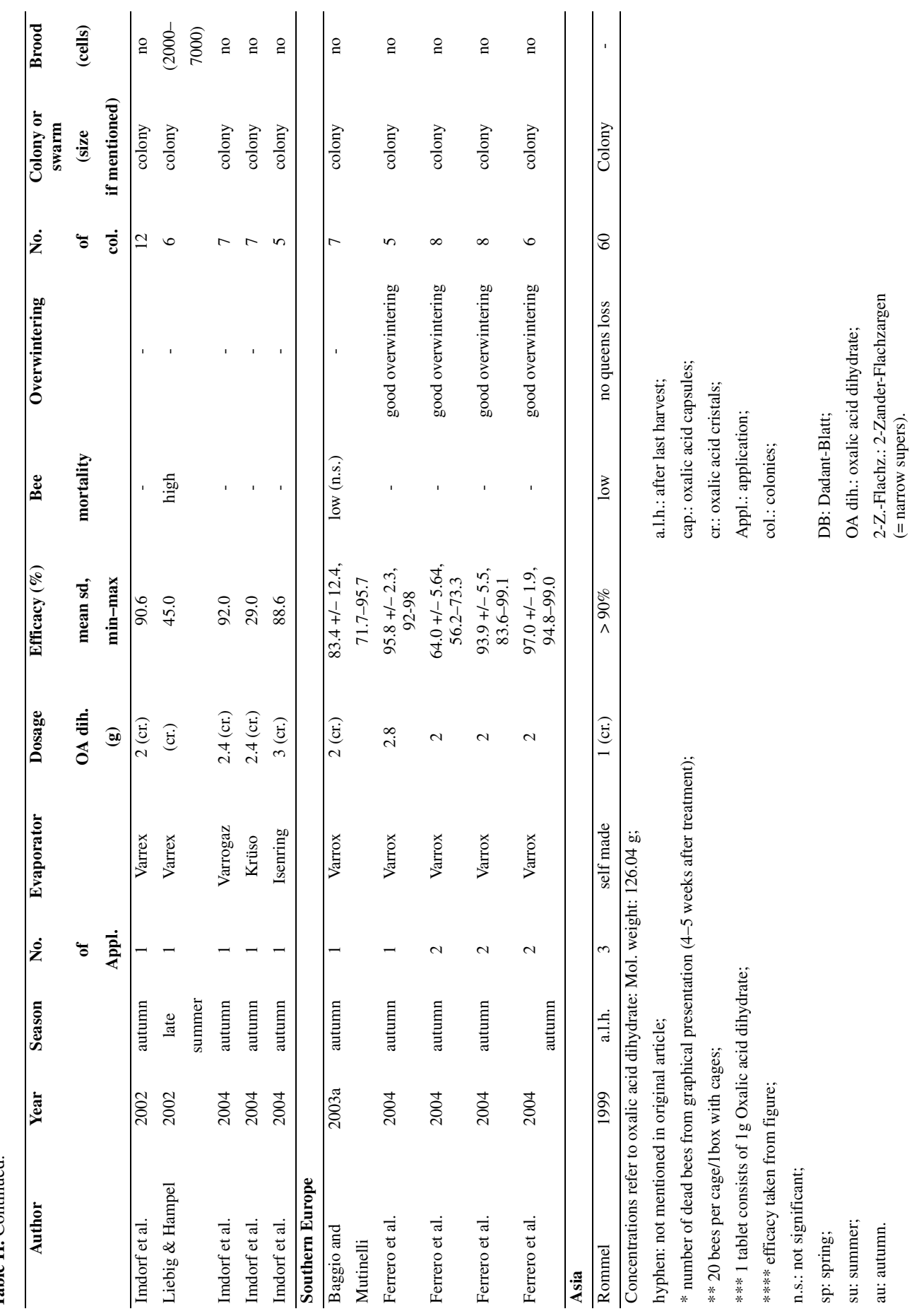


applying the high dosage of $2.8 \mathrm{~g}$ (Radetzki and Bärmann, 2001).

Another electric evaporator (Varrex), constructed in a similar way to the Varrox device, was described by Imdorf et al. (2004). When $2 \mathrm{~g}$ oxalic acid dihydrate was sublimated, an efficiency of $90.6 \%$ was reached in broodless colonies (Imdorf et al., 2002) and 45\% in colonies with brood (Liebig and Hampel, 2002).

In testing three different gas evaporators (Varrogaz, Isenring, Krüso described by Imdorf et al., 2004), which heat with gas burners, only Varrogaz reached mite mortality comparable to the Varrox electrical evaporator. Isenring and Krüso evaporators showed lower efficiencies, although high oxalic acid dihydrate dosages were sublimated (2.4 resp. $3 \mathrm{~g}$ ); Krüso (2.4 g) was least effective with $29 \%$ mite fall (Imdorf et al., 2004).

\subsubsection{Tolerability}

Most authors reported that the evaporation of oxalic acid dihydrate ( 0.5 to $5 \mathrm{~g}$ crystals) with the Varrox evaporator had no impact on bee mortality and colony overwintering; no losses of queens were observed (Baggio and Mutinelli, 2003a; Ferrero et al., 2004; Radetzki, 2001; Radetzki et al., 2000; Radetzki and Bärmann, 2001). Charrière et al. (2004) found that after a single treatment with $2 \mathrm{~g}$ oxalic acid dihydrate higher bee mortality was observed during the winter compared to the control group (15 and 30\% compared to 12 and 16\%), but the differences between the groups were not significant (ANOVA). Observations concerning repeated treatments using the Varrox evaporator did not result in colony damage (Radetzki, 2002).

Moosbeckhofer et al. (2002) tested the tolerability of oxalic acid dihydrate $(1 \mathrm{~g})$ on caged bees, placed in a one-story hive, using the Varrox evaporator. Mortality among treated bees was significantly higher than in control groups, irrespective of the season when the bees emerged.

\subsection{Spraying}

Solutions of oxalic acid dihydrate were sprayed onto the bees on both sides of each comb and the bees resting on the hive walls; spraying was normally carried out during the broodless period. The application took approximately 4-5 minutes per hive. Most trials were conducted in Central Europe at outside temperatures ranging from 5 to $12.3{ }^{\circ} \mathrm{C}$. The investigations are listed in Table III grouped by climatic area, season and dose.

\subsubsection{Efficacy}

The investigations in Central Europe were mostly conducted on broodless colonies. A concentration of $3 \%$ oxalic acid dihydrate and doses of 2.5-4 mL or 3-4 mL per comb side reached efficacies of 97.3 to $98.8 \%$ (Charrière et al., 1998; Charrière et al., 2004; Imdorf et al., 1995; Radetzki, 1994). In colonies with brood, only $61 \%$ of the mites were killed (Charrière et al., 1998). In the warm climate of Southern Europe, the broodless period is very short and mite reproduction high, therefore several treatments may be necessary. Two treatments (7.3 and $6.4 \mathrm{~g}$ per comb side; one gram corresponds here to approximately to one millilitre) conducted by Nanetti et al. (1995) showed high efficacy of $99.5 \%$ in broodless colonies. Trials with repeated treatments (every seven days for four weeks) were carried out when brood was present in the colonies and led to a reduced mite mortality to $73 \%$ in spring and $94 \%$ in autumn, respectively (Higes et al., 1999).

\subsubsection{Tolerability}

Single treatments with $3 \%$ oxalic acid dihydrate solution in a dosage of $2.5-4 \mathrm{~mL}$ or 3$4 \mathrm{~mL}$ per comb side were well tolerated (Charrière et al., 1998; Radetzki, 1994, 2001). None of the colonies lost their queen; bee mortality was not increased. Charrière et al. (2004) described losses during winter (11 to $26 \%$ of the bees per hive) that were slightly, but not significantly, higher compared to the controls (12 to $16 \%$, ANOVA). Even the highest concentration evaluated (5\% oxalic acid dihydrate) caused no further problems; mortality did not increase during the five days after treatment (Radetzki, 1994).

Colonies treated twice with $3 \%$ oxalic acid dihydrate solution ( 7.3 and $6.4 \mathrm{~g}$ per comb side; one gram corresponds here approximately to one millilitre) resulted in high bee mortality averaging 170 dead bees after each administration 


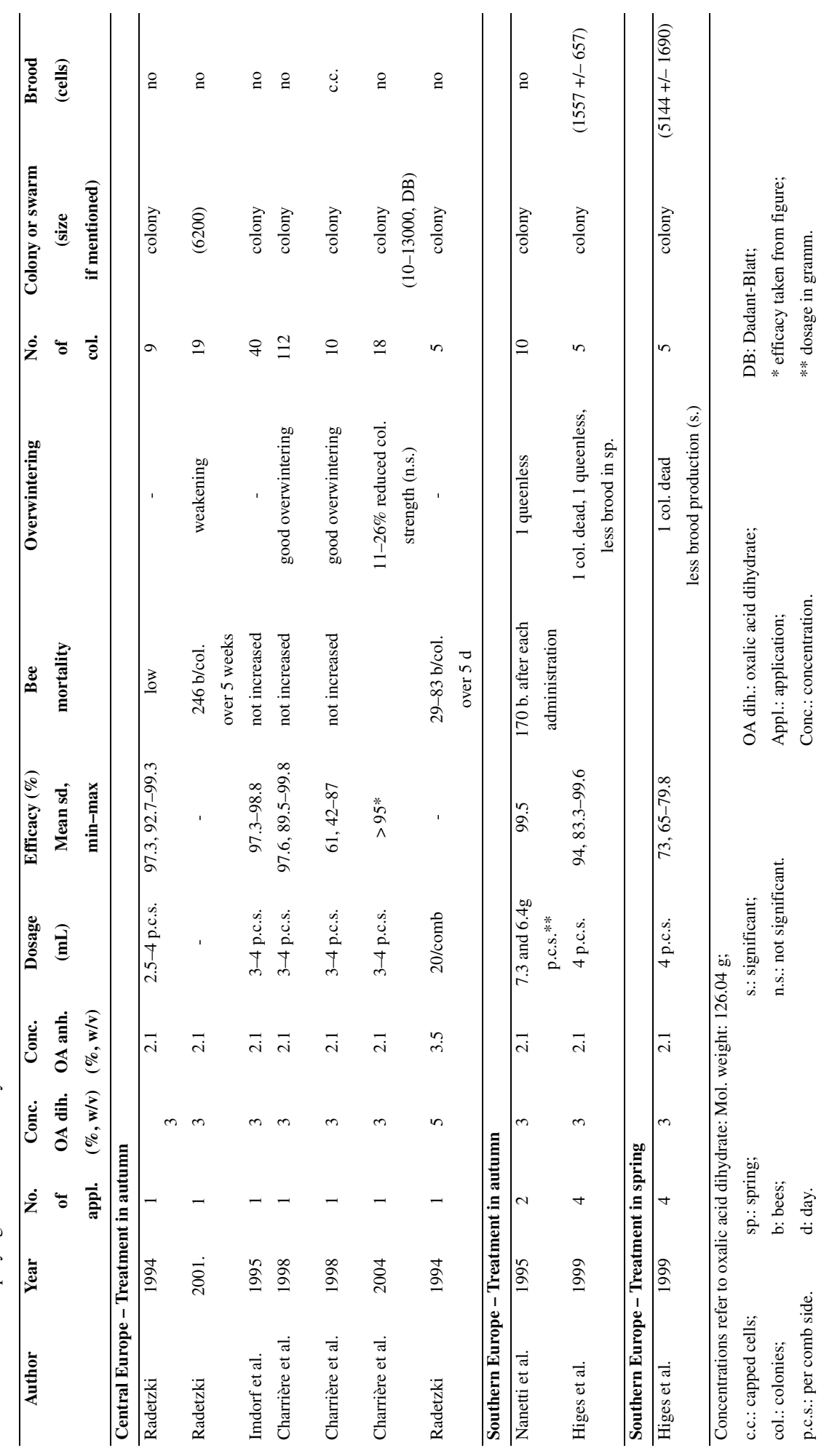


and queen loss in one colony (Nanetti et al., 1995). When oxalic acid dihydrate solution (3\%, $4 \mathrm{~mL}$ per comb side) was applied multiple times during autumn or spring (every seven days for four consecutive weeks) queen and colony losses occurred. Significantly fewer cells containing sealed brood were reported in treated colonies compared to the control groups (Wilcoxon-Mann-Whitney-test, $P<0.05$; Higes et al., 1999).

The effect of oxalic acid on bee larvae was investigated by Gregorc et al. (2004). A solution of $6.5 \mathrm{~g}$ oxalic acid dihydrate / $50 \mathrm{~g}$ sugar/ $100 \mathrm{~mL}$ water sprayed on honey bee larvae ( $0.121 \mathrm{mg} /$ larvae) affected the columnar cells of the midgut, leading to necrosis.

\section{HEALTH AND SAFETY}

Gumpp (2002) studied health and safety issues of the beekeeper with two different application methods: evaporation (Varrox, 12 g oxalic acid dihydrate per hive) and spraying (3\% oxalic acid dihydrate solution, $2.5 \mathrm{~mL}$ per comb side). Air samples were gathered from the beekeeper's working area. Membrane filters were inserted into a standard air sampler connected to an air-collection pump. Two particle fractions were taken: fraction $\mathrm{E}$ (breathable intake of particles) and fraction A (alveolic intake of particles). Ten beekeepers used the evaporation method; ten used the spraying technique. The beekeepers were mostly working with free-standing beehives, but occasionally in bee-houses. When the spraying method was used, air samplers were positioned close to the beekeeper's working area within one meter of the colony. For oxalic acid evaporation the samplers were placed within one meter of the hive entrance. To gain personalized samples a filter was placed on the beekeeper's clothes (fraction A only). After air sampling, oxalic acid-carrying membrane filters were extracted with distilled water and analyzed using HPLC.

Fraction $\mathrm{E}$ : The mean value $(\mathrm{n}=10)$ for the spraying method was $0.22 \mathrm{mg} / \mathrm{m}^{3}$ and $0.23 \mathrm{mg} /$ $\mathrm{m}^{3}$ for evaporation. There was no significant difference between the two methods (ShapiroWilk-test, $P=0.05$ ). Both results stayed significantly under the maximum exposure limit of $1 \mathrm{mg} / \mathrm{m}^{3}$ (MAK-value for Germany, BMA, 2000; TLV-TWA for USA, Department of
Health and Human Services, 2005; MEL for UK, University of Bristol, 2005). A significant difference was found comparing treatments in free-standing bee hives $(\mathrm{n}=15)$ and in beehouses $(\mathrm{n}=5)$ (Shapiro-Wilk-test, $P=0.05)$. The oxalic acid concentration surrounding the free-standing bee hives was lower than in beehouses: the average was $0.15 \mathrm{mg} / \mathrm{m}^{3}$ and $0.30 \mathrm{mg} / \mathrm{m}^{3}$, respectively. Both results were under the maximum exposure limit of $1 \mathrm{mg} / \mathrm{m}^{3}$.

Fraction A: The mean value $(n=10)$ for the spraying method was $0.15 \mathrm{mg} / \mathrm{m}^{3}$ and $0.07 \mathrm{mg}$ / $\mathrm{m}^{3}$ for evaporation. There was no significant difference between the two methods (ShapiroWilk-test, $P=0.05)$. No significant difference was found when comparing treatments in freestanding bee hives $(\mathrm{n}=15)$ and in bee-houses $(\mathrm{n}=5)$ (Shapiro-Wilk-test, $P=0.05)$. The average was $0.06 \mathrm{mg} / \mathrm{m}^{3}$ and $0.18 \mathrm{mg} / \mathrm{m}^{3}$, respectively. The data from personalized samplers $(n=9)$ showed a lower concentration than from the samplers in the beekeepers' working area ( $\mathrm{n}=11): 0.06 \mathrm{mg} / \mathrm{m}^{3}$ resp. $0.18 \mathrm{mg} / \mathrm{m}^{3}$ (ShapiroWilk-test, $P=0.05)$. The results were under the maximum exposure limit of $1 \mathrm{mg} / \mathrm{m}^{3}$.

Gumpp's study provides evidence that oxalic acid dihydrate, when applied correctly, poses no inhalation risk to the beekeepers' health. The existing exposure limit for oxalic acid was not exceeded in any test case. There is no known risk in terms of systemic effects of the compound.

This information is based on the application of oxalic acid with one evaporator. When using multiple systems, as described by Gotti (2004), the oxalic acid concentration in the air surrounding the apiary may increase beyond the values mentioned above. Furthermore, the beekeeper risks contamination when handling oxalic acid crystals. Apart from that, the colonies should not be inspected directly after treatment, because no data is available about oxalic acid concentration in the air of the hive over a period of time. However, to avoid local effects the beekeeper should wear the recommended safety equipment. A FFP2 SL-type face mask sufficiently protects the user (European Regulation EN 149). The apiarist should also wear protective glasses, acid-proof protective gloves and long sleeves to avoid direct contact with oxalic acid dihydrate solution and crystals. A basin for washing hands and an eyewash should be placed in the apiarist's working area. When 
working with oxalic acid dihydrate, bee-houses should be adequately ventilated.

On the basis of the investigation into user safety during the application of oxalic acid dihydrate by either evaporation or spraying techniques, we suggest that the risks from using the trickling method are even lower, because inhalation of oxalic acid is not likely.

\section{RESIDUES AFTER TREATMENT WITH OXALIC ACID}

It is not expected that oxalic acid will accumulate in beeswax and propolis due to its hydrophilic properties. Oxalic acid is a natural component of honey. Concentrations in honey vary between $3.3-761.4 \mathrm{mg} / \mathrm{kg}$ (Nanetti et al., 2003c) depending on the botanical origin of the nectar. Natural values for oxalic acid in honey are, for example: honeydew 38-119 mg/kg; wildflower honey $8-51 \mathrm{mg} / \mathrm{kg}$ (Bogdanov et al., 2002); heather $48-151 \mathrm{mg} / \mathrm{kg}$ and $85.5-$ $168 \mathrm{mg} / \mathrm{kg}$ (Nozal et al., 2000, 2003); honeydew 59-158 mg/kg, oilseed rape honey 13$53 \mathrm{mg} / \mathrm{kg}$ (Pechhacker et al., 2004). Most honeys contain $<200 \mathrm{mg}$ oxalic acid/kg honey (Wibbertmann, 2003). A review of residues after oxalic acid dihydrate treatment of bee colonies are listed in Table IV, grouped by application method, number of treatments and time of year.

\subsection{Trickling}

Single autumn treatments using oxalic acid dihydrate (3.1 to $6 \%, 5 \mathrm{~mL} / \mathrm{bee}$ space) were conducted in several studies. Nanetti and Stradi (1997) reported that the content of oxalic acid in the remaining winter food was not increased. Another investigation by Nanetti et al. (2002) compared the oxalic acid content of spring honey after autumn treatment: higher concentrations up to $76.3 \mathrm{mg} / \mathrm{kg}$ (+/- 18.3) were found, but were still within the natural content levels of honey from various botanical origins. Application of $4.7 \%$ and $10-15 \mathrm{~mL}$ per hive (Moosbeckhofer et al., 2003) did not increase the oxalic acid content of spring honey.

Repeated treatments with oxalic acid dihydrate solutions from 3.5 and $6 \%$ and $50-55 \mathrm{~mL}$ per hive slightly increased the oxalic acid content in honey after treatment by $22 \mathrm{mg} / \mathrm{kg}$
(Floris et al., 1998) and in spring honey by $0.3 \mathrm{mg}$ and $7 \mathrm{mg} / \mathrm{kg}$, respectively (Moosbeckhofer et al., 2003; Bogdanov et al., 2002). In one case, even the highest concentration ( $7 \%$ oxalic acid dihydrate, $25-30 \mathrm{~mL}$ per hive) did not raise the oxalic acid content of the honey directly after treatment (Mutinelli et al., 1997).

Treatments in spring or summer with varying dosages led to somewhat higher oxalic acid contents in the honey after application (Liebig, 1999; Brødsgaard et al., 1999), but the difference was not significant compared to controls (Kruskal-Wallis-test, $P<0.05$; Brødsgaard et al., 1999).

\subsection{Evaporation}

After treating colonies during autumn with the Varrox evaporator (1-5 g oxalic acid dihydrate crystals/tablets) the oxalic acid content of spring honey was within control limits (Radetzki and Bärmann, 2001; Moosbeckhofer and Baumgartner, 2002).

\subsection{Spraying}

Oxalic acid treatments in autumn using $3 \%$ oxalic acid dihydrate solution (3-4 mL per comb side) did not influence the oxalic acid content in spring honey (Bogdanov et al., 2002); however the oxalic acid content of honey after the treatment did increase slightly (Aumeier, 1998).

Repeated application (4 times) in autumn or winter (3\% oxalic acid dihydrate, $50-80 \mathrm{~mL}$ depending on colony size) increased the oxalic acid content in honey after the treatment by 13 and $18 \mathrm{mg} / \mathrm{kg}$, respectively (Floris et al., 1998; Nozal et al., 2000).

In spring (March), a single oxalic acid treatment (3\%, 3-4 mL per comb side) caused a significant increase in the oxalic acid content in honey up to $62.8 \mathrm{mg} / \mathrm{kg}$ eight days after the treatment (Kruskal-Wallis-test, $P<0.05$ ). By June, the levels in honey were back within control limits (Brødsgaard et al., 1999).

\section{CONSUMER SAFETY}

Oxalic acid is an ubiquitous substance in plants and can be found in high concentrations 


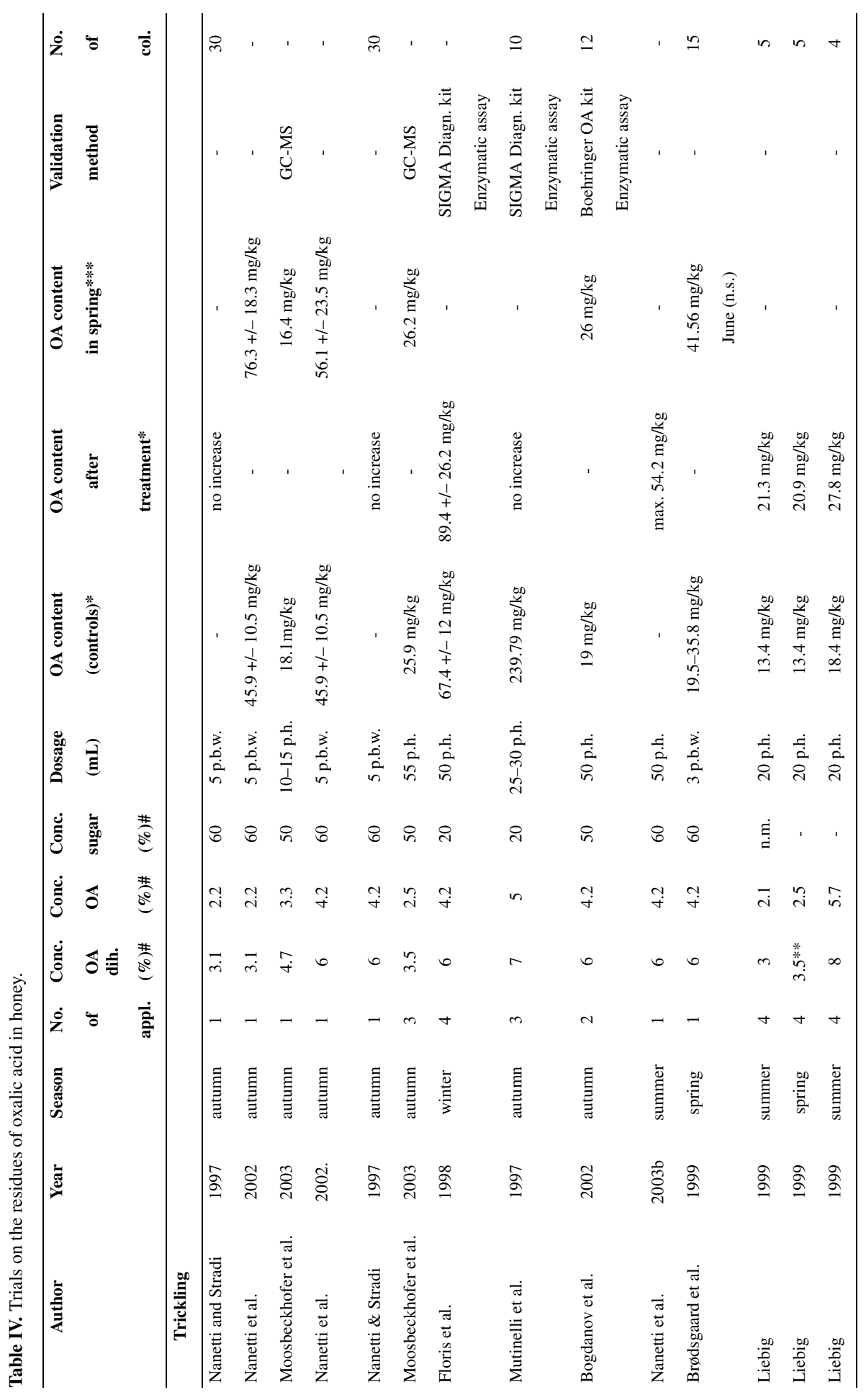




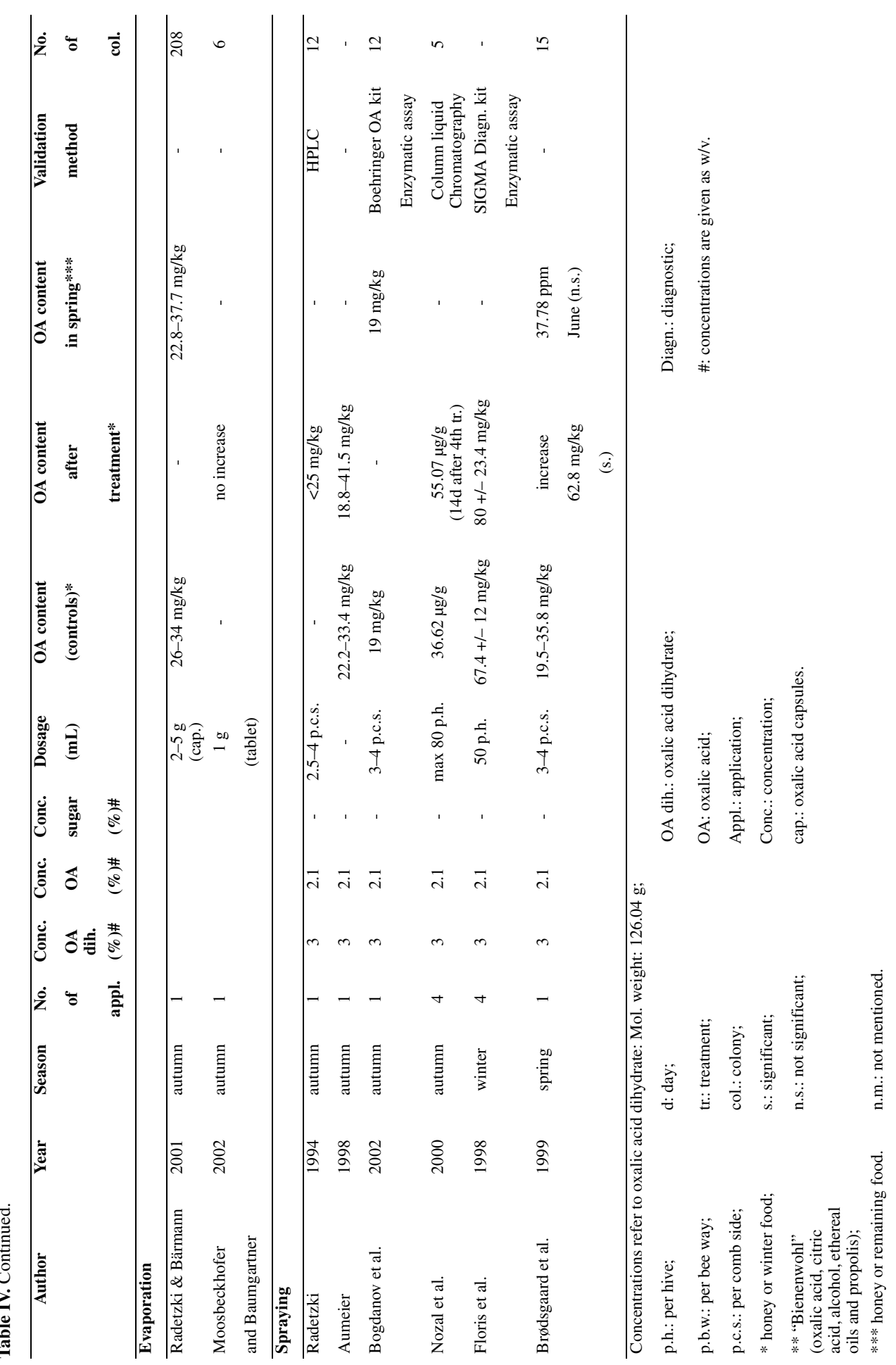


in many vegetables; e.g. spinach, rhubarb, beetroot, tea and cocoa (Holmes and Kennedy, 2000). The oxalic acid content in plants is much higher than in honey. According to Holmes and Kennedy (2000) the oxalic acid content of honey from treated colonies is not or only slightly increased. Even the highest levels found after spring treatment did not exceed the naturally occurring oxalic acid content of honey from various botanical origins. The daily amount of oxalic acid ingested in a European diet is $70-80 \mathrm{mg}$ and can reach up to 400 $600 \mathrm{mg} /$ day in a vegetarian diet (Gay et al., 1984). Poul (2003) estimated the mean daily dietary intake of oxalic acid to be $80 \mathrm{mg} /$ day. An ADI (acceptable daily intake) of $0.89 \mathrm{mg} / \mathrm{kg}$ was suggested; this corresponds to a safe daily intake of $53.4 \mathrm{mg} /$ day for a $60 \mathrm{~kg}$ human. The US Environment Protection Agency concluded that $0.14 \mathrm{mg}$ oxalic acid or oxalate $/ \mathrm{kg} /$ day over a 24-hour-period represents the allowable human exposure from all sources (US EPA, 1992).

Assuming a daily intake of $20 \mathrm{~g}$ honey with a high content of $200 \mathrm{mg}$ oxalic acid/ $\mathrm{kg}$ honey, the additional consumption of oxalic acid will be about $0.067 \mathrm{mg} / \mathrm{kg}$ b.w. for a $60 \mathrm{~kg}$ person (Wibbertman, 2003). The author concluded that this would not cause a risk to human health.

The theoretical oxalic acid intake in honey from either treated or non-treated bee hives is negligible when compared to the daily intake from other sources (Committee for Veterinary Medicinal Products, 2003).

\section{SUMMARY AND RECOMMENDATIONS}

Oxalic acid dihydrate is a suitable compound for the control of $V$. destructor in broodfree colonies during the autumn and winter period within the Concept of Integrated Varroa Control. Oxalic acid achieved very good efficacy against the parasite and tolerability in the target species A. mellifera. Considering the reviewed studies, all three application methods for oxalic acid can be recommended; however, the beekeeper will most likely choose the trickling method since it is the easiest to apply, has the lowest cost and offers the least contact with the acid.

\subsection{Application methods}

\subsubsection{Trickling}

Trickling oxalic acid dihydrate seems to be the most suitable application method, especially for large apiaries. The beekeeper needs only a syringe or a similar applicator, gloves and protective glasses to apply the substance. The application is quick, about $1 \mathrm{~min}$ per hive, cost-effective and easy to conduct.

The method can be used as a standard treatment due to its effectiveness, tolerability and simplicity of application. The recommended oxalic acid dihydrate concentration, which varies across the different European climatic regions, was determined by comparing efficacy and tolerability for Central-, Southern- and Northern Europe. For Central Europe a concentration of $3.5 \%$ oxalic acid dihydrate in sugarwater solution $(1: 1)$ is recommended $(=35 \mathrm{~g}$ oxalic acid dihydrate/litre). The dose of approx. $5 \mathrm{~mL}$ solution should be used per bee space; i.e., $30 \mathrm{~mL}$ on a small colony, $40 \mathrm{~mL}$ on a mediumsize and $50 \mathrm{~mL}$ on a large colony. Recommendations for Southern and Northern Europe are given as follows: for Southern Europe 6\% oxalic acid dihydrate in sugar-water solution $(1: 1)$ (= $60 \mathrm{~g}$ oxalic acid dihydrate/litre) and the dose of $5 \mathrm{~mL}$ per occupied comb, for Northern Europe $4.5 \%$ oxalic acid dihydrate in sugarwater solution $(1: 1)(=45 \mathrm{~g}$ oxalic acid dihydrate/litre) and the dose of 20-25 mL on a small colony, $25-30 \mathrm{~mL}$ on a medium-size and 30$35 \mathrm{~mL}$ on a large colony (European Group for Integrated Varroa Control, 2000).

A single treatment should be conducted during the broodless period at an outside temperature of $>3{ }^{\circ} \mathrm{C}$. Repeated and summer treatments are not recommended as they result in a high level of bee mortality and low efficacy, respectively, due to large numbers of capped brood cells.

\subsubsection{Evaporation}

Beekeepers using the evaporation method will have additional expenses; e.g., safety equipment and an evaporator. They need to wear gloves, a face mask and protective glasses. The Varrox evaporator used in most trials (Central Europe) showed good efficacy and tolerability when 1-2 g oxalic acid dihydrate 
was vaporized depending on colony size and beehive type. One $\mathrm{g}$ is sufficient for treating single-story hives, larger hives (e.g. Dadant or two-story hives) should be treated with $2 \mathrm{~g}$. A greater level of user protection can be achieved by using oxalic acid tablets ( $1 \mathrm{~g}$ oxalic acid dihydrate/tablet) in the Varrox evaporator, as there is no direct contact with the crystals. The single application should be conducted during the broodless period at an outside temperature of $>2{ }^{\circ} \mathrm{C}$, and takes about $4 \mathrm{~min}$ per hive.

\subsubsection{Spraying}

Spraying oxalic acid is more time-consuming than trickling, as every comb must be removed from the hive; therefore it is most likely to be used in small apiaries. The recommended dose is based on trials conducted in Central Europe: a water solution of $3 \%$ oxalic acid dihydrate (= $30 \mathrm{~g}$ oxalic acid dihydrate/ litre water) is sprayed onto the bees on either side of the combs and onto bees resting on the hive walls. A dose of 3-4 mL solution should be used per occupied comb side; i.e., approximately $50 \mathrm{~mL}$ on a small colony, $65 \mathrm{~mL}$ on a medium-size colony, $80 \mathrm{~mL}$ on a large colony. The single treatment should be conducted during the broodless period at an outside temperature of $>5{ }^{\circ} \mathrm{C}$, and takes approximately 4 5 minutes per hive.

\subsection{Health and safety, residues and consumer safety}

Assuming that the beekeeper uses oxalic acid according to the recommended health and safety instructions and wears protective clothing, the treatment poses no risk to the apiarist's health. Autumn treatment with oxalic acid dihydrate, according to the methods and dosages described, causes no evident increase of natural oxalic acid content in honey, and there is therefore no risk to human health from consuming the honey.

\subsection{Legalisation of the use of oxalic acid as a drug in bees}

Research on oxalic acid has been conducted for beekeepers, but its use as a drug in honey bee colonies is strongly regulated by legisla- tion. Without formal approval the treatment remains illegal.

In all EU countries, government approval is only given to a new veterinary drug after the European Union's Agency for Evaluating Medical Products (EMEA) has determined the maximum residue limit (MRL) of the active ingredient allowed in the final food product according to Council Regulation (EEC) 2377/ 90 (Mutinelli and Rademacher, 2002). This procedure is intended to protect consumers from dangerous residues in food resulting from medicines used on animals. Conducted as a common European project by scientific institutes and beekeeper organisations from most European countries, oxalic acid was listed in Annex II of Council Regulation (EEC) 2377/90 in December 2003 (Rademacher and Imdorf, 2004). This means that the substance is declared not dangerous and that no residue limit is needed to protect the consumer. On this basis every European country can apply for legal approval of oxalic acid as a drug in bee colonies.

\section{ACKNOWLEDGEMENT}

Special acknowledgement is given to the Bayerisches Staatsministerium für Umwelt, Gesundheit und Verbraucherschutz for their financial support.

Résumé - L'acide oxalique comme moyen de lutte contre la varroose dans les colonies d'abeilles - une synthèse. Depuis l'arrivée de l'acarien ectoparasite Varroa destructor Anderson and Trueman dans les colonies d'abeilles domestiques (Apis mellifera L.), les apiculteurs doivent régulièrement traiter à l'acaricide pour maintenir le parasite sous le seuil de dégâts économiques. Au cours des 10 dernières années les acariens ont développé un nombre croissant de résistances aux acaricides de synthèse si bien que de nouveaux produits vétérinaires sont nécessaires pour combattre la varroose.

Cet article donne une vue d'ensemble sur l'acide oxalique utilisé comme acaricide contre $V$. destructor en goutte à goutte, par évaporation et pulvérisation. L'acide oxalique est un acide largement répandu dans le règne végétal; il est présent dans de nombreux légumes, comme l'épinard, la betterave rouge ou la rhubarbe, et aussi dans le miel. Contre la varroose le dihydrate d'acide oxalique est appliqué (a) par dégouttement dans une solution sucrée directement sur les abeilles dans les passages entre les cadres, (b) sous forme de cristaux qui se subliment dans la ruche ou (c) par pulvérisation d'une solution aqueuse sur les abeilles qui se tiennent sur les rayons. 
Pour évaluer l'acide oxalique comme acaricide on a prit en compte l'efficacité, la tolérance par les abeilles, la protection de l'utilisateur, la teneur en résidus et la sécurité pour le consommateur. Les tableaux I à III regroupent les données disponibles concernant l'efficacité et la tolérance par les abeilles des divers modes d'application en fonction de la dose appliquée, de la concentration en sucre de la solution utilisée, de la période et de la fréquence de traitement et de la zone climatique. Sous ses trois modes d'application l'acide oxalique est efficace à $90 \%$ et bien toléré par les abeilles. Par sa facilité d'application le dégouttement paraît particulièrement bien convenir à la pratique apicole.

L'application d'acide oxalique n'occasionne aucun ennui de santé chez l'utilisateur s'il l'utilise de façon appropriée et porte des vêtements de protection adaptés. En ce qui concerne la protection du consommateur et les résidus éventuels, on part du principe que l'acide oxalique, par des propriétés hydrophiles, ne se concentre pas dans la cire ni dans la propolis. La teneur naturelle du miel en acide oxalique est très variable $(3,3-761,4 \mathrm{mg} / \mathrm{kg})$ et dépend de l'origine botanique du nectar. Après application de dihydrate d'acide oxalique sa concentration augmente dans le miel ou dans les réserves d'hiver, puis les valeurs redescendent aux niveaux naturels au printemps suivant (Tab. IV). L'acide oxalique a été inscrit en décembre 2003 à l'Annexe II du Règlement 2377/90 du Conseil de l'U.E. par l'EMEA (Agence Européenne pour l'Évaluation des Médicaments) ; cela signifie que la substance est non dangereuse pour le consommateur et que toute limite supérieure de résidu est inutile.

L'acide oxalique convient pour traiter les colonies à l'automne et en hiver dans le cadre d'une lutte intégrée. Il se caractérise par une efficacité élevée, une bonne tolérance par les abeilles, une facilité d'application pour l'apiculteur et par une situation des résidus dans le miel favorable.

varroose / acide oxalique / résidu / efficacité / sécurité des consommateurs / Varroa destructor

Zusammenfassung - Oxalsäure zur Bekämpfung der Varroose an Bienenvölkern. Seit Auftreten des Parasiten Varroa destructor in Bienenvölkern von Apis mellifera müssen Imker regelmäßig Akarizide einsetzen, um den Ektoparasiten unterhalb der Schadensschwelle zu halten. In den letzten 10 Jahren entwickelten sich zunehmend Resistenzen der Milben gegenüber den synthetischen Akariziden, so dass weitere Tierarzneimittel zur Bekämpfung der Varroose nötig wurden.

Der vorliegende Artikel gibt einen Überblick über Oxalsäure als Akarizid zur Bekämpfung der Varroose in den Applikationsformen Träufeln, Verdampfen und Sprühen. Oxalsäure ist eine weit verbreitete Pflanzensäure, die in vielen Gemüsen wie z.B. Spinat, Rharbarber oder Rote Beete und auch im Honig vorkommt. Zur Behandlung der Varroose wird Oxalsäuredihydrat (a) in Zuckerwasserlösung auf die Bienen in den Wabengassen geträufelt, (b) als Kristalle im Volk sublimiert oder (c) als wässrige Lösung auf die bienenbesetzten Waben gesprüht. Bei der Bewertung der Oxalsäure als Akarizid wurden Wirksamkeit und Bienenverträglichkeit, Anwenderschutz sowie Rückstandsbelastung und Verbrauchersicherheit berücksichtigt. Die verfügbaren Daten zu Wirksamkeit und Bienenverträglichkeit der verschiedenen Behandlungsmethoden bezüglich applizierter Dosis, Zuckerkonzentration der verwendeten Lösung, Behandlungszeitpunkt und -häufigkeit sowie der Klimazone sind in Tabelle I-III zusammengestellt. Bei allen drei Applikationsformen sind Wirksamkeiten von über $90 \%$ bei guter Bienenverträglichkeit zu erzielen. Träufeln erscheint wegen einfacher Anwendung in der imkerlichen Praxis als besonders geeignet.

Die Applikation von Oxalsäure verursacht bei sachgemäßer Handhabung und Tragen geeigneter Schutzkleidung kein Gesundheitsrisiko für den Anwender. Hinsichtlich des Verbraucherschutzes und der Rückstandssituation ist davon auszugehen, dass sich Oxalsäure aufgrund der hydrophilen Eigenschaften nicht in Wachs und Kittharz anreichert. Der natürliche Gehalt an Oxalsäure im Honig ist sehr unterschiedlich $(3,3-761,4 \mathrm{mg} / \mathrm{kg})$ und abhängig von der botanischen Herkunft des Nektars. Nach der Applikation von Oxalsäuredihydrat erhöht sich die Konzentration im Honig oder Winterfutter. Bis zur nächsten Trachtperiode im Frühjahr sinken die Werte wieder auf die natürlichen Gehalte ab (Tab. IV). Oxalsäure wurde im Dezember 2003 von der EMEA (European Union's Agency for Evaluating Medical Products) in Annex II der Council Regulation (EEC) 2377/90 aufgenommen, was bedeutet, dass kein nomineller Wert für die Rückstandshöchstmenge zum Schutz des Verbrauchers festgelegt werden muß.

Oxalsäure ist eine geeignete Substanz für die Herbst - Winterbehandlung, um im Rahmen des integrierten Bekämpfungskonzeptes Varroa destructor unter der Schadensschwelle zu halten. Oxalsäure zeichnet sich durch hohe Wirksamkeit gegen den Parasiten, gute Verträglichkeit am Zieltier Biene, einfache Anwendung für den Imker sowie eine günstig zu bewertende Rückstandssituation im Honig aus.

Oxalsaüre / Varrose / Honigbiene / Rückstände

\section{REFERENCES}

Arbeitgemeinschaft der Institute für Bienenforschung e. V. (2001) Varroa unter Kontrolle, Wie wird's gemacht? Dtsch. Bienenj. 5 (Beilage).

Aumeier P. (1998) Alternativ hat Zukunft, Der „Hohenheimer Tag“ 1998, Allg. Dtsch. Imkerztg. $8,17-20$.

Baggio A., Mutinelli F. (2003a) Varroosis control in broodless time: oxalic acid and Varrox, Meeting of the European Group for Integrated Varroa 
Control, Rauischholzhausen, [online] http:// www.apis.admin.ch/host/varroa/rauisch.htm (accessed on 27 July 2005).

Baggio A., Mutinelli F. (2003b) Integrated Varroa control: Oxavar and oxalic acid, Meeting of the European Group for Integrated Varroa Control, Rauischholzhausen, [online] http://www.apis. admin.ch/host/varroa/rauisch.htm (accessed on 27 July 2005).

BMA, Bundesministerium für Arbeit und Sozialordnung (2000) TRGS 900: Grenzwerte in der Luft am Arbeitsplatz, BArbB1. (10), 34-63, zuletzt geändert BArbBl. 3/2002, p. 110, [online] http:// www umwelt-online de/recht/t regeln/tros/tros900/mak_ges.htm (accessed on 20 October 2005).

Bogdanov S., Imdorf A., Charrière J.D., Fluri P., Kilchenmann V. (2002) Determination of residues in honey after treatments with formic and oxalic acid under field conditions, Apidologie 33, 399409.

Brødsgaard C.J., Jensen S.E., Hansen C.W., Hansen H. (1999) Spring treatment with oxalic acid in honeybee colonies as varroa control, DIAS report, Horticulture 6, 16 [online] http://www.danishbee.com/cjb/oxal-djf.htm (accessed on 26 July 2005).

Büchler R. (1998) Überprüfung der Bienenverträglichkeit von Oxalsäure an Kunstschwärmen, Allg. Dtsch. Imkerztg. 11, 21-23.

Büchler R. (1999) Versuchsergebnisse zur Varroatosebekämpfung durch Aufräufeln von Oxalsäurelösung auf die Wintertraube, Allg. Dtsch. Imkerztg. 10, 5-8.

Büchler R. (2000) Oxalsäure - Erfolg mit Nebenwirkungen. Aufträufelmethode beeinträchtigt die Auswinterungsstärke, Allg. Dtsch. Imkerztg. 11, 6-8.

Büchler R. (2002) Winterbehandlungsmethoden im Test. Auswirkungen auf die Volksentwicklung, Allg. Dtsch. Imkerztg. 11, 10-13.

Charrière J.D. (2001) Optimisation of the oxalic acid trickling method and bee tolerability of different winter treatments: trials in Liebefeld during the last 3 years, Meeting of the European Group for Integrated Varroa Control, York, [online] http:// www.apis.admin.ch/host/varroa/york.htm (accessed on 27 July 2005).

Charrière J.D., Imdorf A. (2002) Oxalic acid treatment by trickling against Varroa destructor: recommendations for use in Central Europe and under temperate climate conditions, Bee World $83,51-60$.

Charrière J.D., Imdorf A., Fluri P. (1998) Was kann von der Oxalsäure gegen Varroa erwartet werden? Schweiz. Bienen-Ztg. 8, 503-506.

Charrière J.D., Imdorf A., Kuhn R. (2004) Bienenverträglichkeit von Varroabehandlungen im Winter, Schweiz. Bienen-Ztg. 4, 19-23.

Committee For Veterinary Medicinal Products (2003) Oxalic Acid-Summary Report, EMEA, EMEA/
MRL/891/03, [online] http://www.emea.eu.int/ $\mathrm{pdfs} / \mathrm{vet} / \mathrm{mrls} / 089103$ en.pdf (accessed on 27 July 2005).

Department of Health and Human Services, Center for Disease Control and Prevention (2005) Oxalic Acid, [online] http://www.cdc.gov/niosh/pel88/ 144-62.html (accessed on 27 July 2005).

Elzen P.J., Eischen F.A., Baxter J.B., Pettis J., Elzen G.W., Wilson W.T. (1998) Fluvalinate resistance in Varroa jacobsoni from several geographic locations, Am. Bee J. 9, 674-676.

European Group for Integrated Varroa Control (1999) Coordination in Europe of research on integrated control of Varroa mites in honey bee colonies, Meeting November 13-14, 1999, Merelbeke, Belgium, [online] http://www.apis.admin.ch/host/ doc/pdfvarroa/Merelbeke.pdf (accessed on 20 October 2005)

European Group for Integrated Varroa Control (2000) Minutes from the 5th Meeting, Bern 16-17 June 2000, [online] http://www.apis.admin.ch/english/ host/pdf/alternativ/bern.pdf (accessed on 27 July 2005).

Ferrero R., Ferrazzi P., Nanetti A. (2004) Lotta contro Varroa destructor (Anderson and Trueman) con acido ossalico somministrato mediante sublimazione o per gocciolamento di soluzioni zuccherine, Apoidea 1, 66-71.

Floris I., Satta A., Mutinelli F., Prandin L. (1998) Efficiency of winter applications of oxalic acid against Varroa jacobsoni Oud. in beehives in a Mediterranean area, Redia 81, 143-150.

Fries I. (2001) Is the total amount or the concentration of oxalic acid critical for efficacy in varroa mite control? European Group for Integrated Varroa Control, York, [online] http://www.apis. admin.ch/host/varroa/york.htm (accessed on 27 July 2005).

Gay V., Guardiola P., Vallon J.J. (1984) L'acide oxalique: métabolisme, physiopathologie et méthodes de dosage, Lyon Pharm. 35, 69-78.

Gotti M. (2004) Studio sulle possibilita di utilizzo nella lotta alla varroasi di evaporatori Varrox in multiplo, Lapis 12, 5-9.

Gregorc A., Planinc I. (2001) Acaricidal effect of oxalic acid in honey bee (Apis mellifera) colonies, Apidologie 32, 333-340.

Gregorc A., Pogacnik A., Bowen I.D. (2004) Cell death in honey bee (Apis mellifera) larvae treated with oxalic or formic acid, Apidologie 35, 453 460.

Gumpp T.J. (2002) Untersuchungen zur Arbeitssicherheit des Imkers bei der Anwendung von Oxalsäure zur Bekämpfung der Varroatose, Doktorarbeit am Institut für Arbeits- und Sozialmedizin, Universitätsklinikum Tübingen, [online] http://w210.ub.uni-tuebingen.de/dbt/volltexte/ 2004/1181/pdf/Arbeitssicherheit Oxalsaeure Varroatose.pdf (accessed on 20 October 2005).

Higes M., Meana A., Suarez M., Llorente J. (1999) Negative long-tem effects on bee colonies treated 
with oxalic acid against Varroa jacobsoni Oud., Apidologie 30, 289-292.

Holmes R.P., Kennedy M. (2000) Estimation of the oxalate content of foods and daily oxalate intake, Kidney Int. 57, 1662-1667.

Imdorf A., Charrière J.D., Bachofen B. (1995) Wann ist die Oxalsäure als Varroazid geeignet? Schweiz. Bienen-Ztg. 7, 389-391.

Imdorf A., Bogdanov S., Ibanez Ochoa R., Calderone N.W. (1999) Use of essential oils for the control of Varroa jacobsoni Oud. in honey bee colonies, Apidologie 30, 209-228.

Imdorf A., Charrière J.D., Feuz A., Kuhn R. (2002) Oxalsäureverdampfung-Vergleich verschiedener Verdampfungsgeräte, unpublished data (available on request to the author at Swiss Bee Research Centre, FAM Liebefeld, Bern, Switzerland, http://www.apis.admin.ch).

Imdorf A., Kuhn R., Feuz A. (2004) Unterschiedliche Wirksamkeit von Oxalsäure-Verdampfungsgeräten, Schweiz. Bienen-Ztg. 4, 19-23.

Kraus B., Berg S., Schulz A., Otten C. (1993) Untersuchungen zur Bekämpfung der Varroatose mit Milchsäure, unpublished data (available on request to the author at Staatliche Lehr- und Versuchsanstalt für Landwirtschaft, Wein- und Gartenbau, Fachbereich Bienenkunde, Ahrweiler/ Mayen, Germany, http://www.bienenkunde.rlp.de).

Liebig G. (1997) Neue Methoden der Varroatosebekämpfung. Aufträufeln von Oxalsäure und Zitronensäure, Dtsch. Bienenj. 3, 7.

Liebig G. (1998) Zur Eignung des Aufräufelns von Oxalsäure für die Varroabehandlung, Dtsch. Bienenj. 6, 4-6.

Liebig G. (1999) Zur Behandlung von Bienenvölkern mit Oxalsäure und "Bienenwohl", Dtsch. Bienenj. $10,4-5$.

Liebig G., Hampel K. (2002) Zur Anwendung von Oxalsäure durch Verdampfen? Dtsch. Bienenj. 2, $17-18$.

Lodesani M., Colombo M., Spreafico M. (1995) Ineffectiveness of Apistan ${ }^{\circledR}$ treatment against the mite Varroa jacobsoni Oud. in several districts of Lombardy (Italy), Apidologie 26, 67-72.

Milani N. (1995) The resistance of Varroa jacobsoni Oud. to pyrethroids: a laboratory assay, Apidologie 26, 415-429.

Moosbeckhofer R., Trouiller J. (1996) Apistanresistente Varroamilben in Österreich entdeckt, Bienenvater 10, 372-373.

Moosbeckhofer R. (2001) Varroabekämpfung mit Oxalsäure im Träufelverfahren, Bienenvater 12, 7-12.

Moosbeckhofer R., Baumgartner M. (2002) Erste Ergebnisse zur Varroabekämpfung in Österreich, Bienenvater 11, 9-12.

Moosbeckhofer R., Baumgartner M., Licek E., Pechhacker H. (2002) Effects of oxalic acid evaporation on bee mortality in cage tests, unpublished data (available on request to the author at Institute for Apiculture (AGES), Vienna, Austria, http:// www.ages.at).

Moosbeckhofer R., Pechhacker H., Unterweger H., Bandion F., Heinrich-Lenz A. (2003) Investigations on the oxalic acid content of honey from oxalic acid treated and untreated bee colonies, Eur. Food Res. Technol. 217, 49-52.

Mutinelli F., Baggio A. (2002) Ipereat and oxalic acid in the control of varroosis. Two years of trials, European Group for Integrated Varroa Control, Bologna, [online] http://www.apis.admin.ch/ host/varroa/bolognia.htm (accessed on 27 July 2005).

Mutinelli F., Rademacher E. (2002) European legislation governing the use of drugs in bee colonies to control varroosis: A Case Study, The Regulatory Affairs J. 13, 401-406.

Mutinelli F., Baggio A., Capolongo F., Piro R., Prandin L., Biasion L. (1997) A scientific note on oxalic acid by topical application for the control of varroosis, Apidologie 28, 461-462.

Nanetti A., Stradi G. (1997) Oxalsäure-Zuckerlösung zur Varroabekämpfung, Allg. Dtsch. Imkerztg. $11,9-11$.

Nanetti A., Massi S., Mutinelli F., Cremasco S. (1995) L'acido ossalico nel controllo della varroasi: note preliminari, Apitalia 3, 29-32.

Nanetti A., Marcazzan G.L., Massi S., Piro R. (2002) Residui di acido ossalico nel miele alveari trattati contro la varroa, unpublished data (available on request to the author at Instituto Nazionale di Apicoltura, Bologna, Italy, http://www.inapicoltura.org).

Nanetti A., Büchler R., Charrière J.D., Fries I., Helland S., Imdorf A., Korpela S., Kristiansen P. (2003a) Oxalic acid treatments for Varroa control (Review), Apiacta 38, 81-87.

Nanetti A., Bartolomei P., Bellato S., de Salvio M., Gattavecchia E., Ghini S. (2003b) Pharmacodynamics of oxalic acid in the honey bee colony, unpublished data (available on request to the author at Instituto Nazionale di Apicoltura, Bologna, Italy, http://www.inapicoltura.org).

Nanetti A., Ghini S., Gattavecchia E., Bartolomei P., Marcazzan G.L., Massi S. (2003c) Pharmacodynamics of oxalic acid and treatment residues in honey, European Group for Integrated Varroa Control, Rauischholzhausen, [online] http:// www.apis.admin.ch/host/varroa/rauisch.htm (accessed on 27 July 2005).

Nasr M.E., Servos D., Bannister R., Wilson G. (2001) Efficacy of three miticides (Oxalic acid, Formic acid, Apilife Var) on Varroa destructor and Acarapis woodi in honey bee colonies in Canada, European Group for Integrated Varroa Control, York, [online] http://www.apis.admin.ch/host/ varroa/york.htm (accessed on 27 July 2005).

Nozal M.J., Bernal J.L., Diego J.C., Gomez L.A., Ruiz J.M., Higes M. (2000) Determination of oxalate, 
sulfate and nitrate in honey and honeydew by ionchromatography, J. Chromatogr. A 881, 629-638.

Nozal M.J., Bernal J.L., Gomez L.A., Higes M., Meana A. (2003) Determination of oxalic acid and other organic acids in honey and in some anatomic structures of bees, Apidologie 34, 181188.

Pechhacker H., Pechhacker M., Heigl H., Moosbeckhofer R., Bandion F., Heinrich-Lenz A., Unterweger H. (2004) Der natürliche Oxalsäuregehalt österreichischer Honige, Bienenvater 125, 12-16.

Popov E.T., Melnik V.N., Matchinev A.N. (1989) Application of oxalic acid in varroatosis, Proc. XXXII Int. Congr. Apimondia, Rio de Janeiro, Apimondia Publ. House, Bucharest, p. 149.

Poul J.M. (2003) Oxalic acid dihydrate. Safety file of the MRL Dossier, unpublished data (available on request to the author at Agence Francaise de Sécurité Sanitaire des Aliments (AFSSA), Laboratoire d'Études et de Recherches sur les Médicaments Vétérinaires et les Désinfectants, Fougères, France, http://www.fougeres.afssa.fr).

Rademacher E. (1995) Eine neue Applikationsform der Ameisensäure (Teil I), Allg. Dtsch. Imkerztg. 7, 6-9.

Rademacher E. (1996) Eine neue Applikationsform der Ameisensäure (Teil II), Allg. Dtsch. Imkerztg. 1, 24-26.

Rademacher E., Imdorf A. (2004) Legalisation of the use of oxalic acid in Varroa control, Bee World $85,70-72$.

Rademacher E., Brückner D., Otten Ch., Radtke J. (1999) Varroatosebekämpfung mit Ameisensäure im Applikator bei unterschiedlichen Betriebsweisen und Standortbedingungen, Dtsch. Bienenj. 9, 4-7.

Radetzki T. (1994) Oxalsäure, eine weitere organische Säure zur Varroabehandlung, Allg. Dtsch. Imkerztg. 12, 11-14.

Radetzki T. (2000) Varroa control with oxalic acid a new application. Field experiments winter 1999/2000, Meeting of the European Group for Integrated Varroa Control, Bern, unpublished data (available on request to the author at Swiss
Bee Research Centre, FAM Liebefeld, Bern, Switzerland, http://www.apis.admin.ch).

Radetzki T. (2001) Varroa control with oxalic acid evaporation. Assessment of the impact for the bees, Meeting of the European Group for Integrated Varroa Control, York, unpublished data (available on request to the author at Swiss Bee Research Centre, FAM Liebefeld, Bern, Switzerland, http://www.apis.admin.ch).

Radetzki T. (2002) Bessere Bienenverträglichkeit der Oxalsäure-Verdampfung, Bienenwelt 11, 15.

Radetzki T., Bärmann M. (2001) Verdampfungsverfahren mit Oxalsäure. Feldversuch mit 1509 Völkern im Jahr 2000, Allg. Dtsch. Imkerztg. 9, 20-23.

Radetzki T., Bärmann M., Sicurella G. (2000) Neue Anwendungstechnik in Testphase - OxalsäureVerdampfungsmethode ohne Einfluß auf Bienentotenfall, Allg. Dtsch. Imkerztg. 11, 9-11.

Rommel W. (1999) Varroabekämpfung: Erfahrungen aus Russland und Kasachstan, Allg. Dtsch. Imkerztg. 2, 24-25.

Schuster H., Schürzinger F. (2003) Oxalsäure zur Sommerbehandlung? Allg. Dtsch. Imkerztg. 1, 27-28.

Spinks R. (2002) Effects of oxalic acid on overwintering colonies in England, European Group for Integrated Varroa Control, Bologna, [online] http://www.apis.admin.ch/host/varroa/ bolognia.htm. (accessed on 27 July 2005).

United States Environmental Protection Agency, R.E.D. (1992) Facts Oxalic Acid, Office of Prevention, Pesticides and Toxic Substances (7508W), EPA 738-F-92-014, [online] www. epa.gov/oppsrrd1/REDs/factsheets/4070fact.pdf (accessed on 27 July 2005).

University of Bristol (2005) School of Chemistry, Exposure Limits, [online] http://www.chm.bris. ac.uk/safety/Explimits.htm (accessed on 27 July 2005).

Wibbertmann A. (2003) Oxalic acid dihydrate. Residue file of the MRL Dossier, unpublished data (available on request to the author at Fraunhofer Institute of Toxicology and Experimental Medicine, Hannover, Germany, http://www.item.fraunhofer.de). 